\title{
Article \\ Cricket Meal (Gryllus bimaculatus) as a Protein Supplement on In Vitro Fermentation Characteristics and Methane Mitigation
}

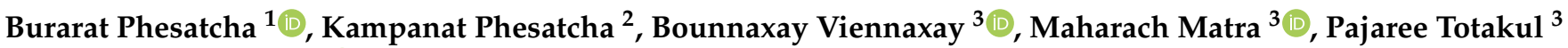 \\ and Metha Wanapat ${ }^{3, * \mathbb{D}}$ \\ 1 Department of Agricultural Technology and Environment, Faculty of Sciences and Liberal Arts, \\ Rajamangala University of Technology Isan, Nakhon Ratchasima 30000, Thailand; Burarat_kat@hotmail.co.th \\ 2 Department of Animal Science, Faculty of Agriculture and Technology, Nakhon Phanom University, \\ Nakhon Phanom 48000, Thailand; kamphe@npu.ac.th or kampanatmon@gmail.com \\ 3 Tropical Feed Resources Research and Development Center (TROFREC), Department of Animal Science, \\ Faculty of Agriculture, Khon Kaen University, Khon Kaen 40002, Thailand; bounnaxay@gmail.com (B.V.); \\ mos-matra@hotmail.com (M.M.); pajaree_totakul@hotmail.com (P.T.) \\ * Correspondence: metha@kku.ac.th; Tel.: +66-4320-2368
}

check for updates

Citation: Phesatcha, B.; Phesatcha, K.; Viennaxay, B.; Matra, M.; Totakul, P.; Wanapat, M. Cricket Meal (Gryllus bimaculatus) as a Protein Supplement on In Vitro Fermentation

Characteristics and Methane

Mitigation. Insects 2022, 13, 129.

https: / / doi.org/10.3390/

insects13020129

Academic Editor: Juan

A. Morales-Ramos

Received: 25 November 2021

Accepted: 20 January 2022

Published: 25 January 2022

Publisher's Note: MDPI stays neutral with regard to jurisdictional claims in published maps and institutional affiliations.

Copyright: (C) 2022 by the authors. Licensee MDPI, Basel, Switzerland. This article is an open access article distributed under the terms and conditions of the Creative Commons Attribution (CC BY) license (https:// creativecommons.org/licenses/by/ $4.0 /)$.
Simple Summary: Protein sources of high quality and sustainability are found in insects. In many regions, insects are a primary food source, such as in Africa, South America, Asia, and Oceania. Insects are considered promising alternative feed sources, in particular as a source of protein. The use of edible insects as high-protein sources is widespread, and cricket has been proved to be a potential food and feed insect species. Cricket (Gryllus bimaculatus) also contain $54.10 \%$ crude protein, $6.90 \%$ crude fiber, $26.90 \%$ fat, and $78.90 \%$ total digestible nutrient, as well as a variety of essential amino acids, including methionine, lysine, histidine, valine, and leucine. In addition, insects have been investigated as a source of protein in diets of poultry, swine, and fish. However, there are currently little data on the utilization of insects as ruminant feed. The objective of this experiment was to conduct the effects of Cricket meal (Gryllus bimaculatus) (CM) as a protein replacement for soybean meal on in vitro fermentation end products, gas production, nutrient degradability, and methane mitigation.

Abstract: The aim of this work was to conduct the effects of cricket (Gryllus bimaculatus) meal (CM) as a protein supplement on in vitro gas production, rumen fermentation, and methane $\left(\mathrm{CH}_{4}\right)$ mitigation. Dietary treatments were randomly assigned using a completely randomized design (CRD) with a $2 \times 5$ factorial arrangement. The first factor was two ratios of roughage to concentrate (R:C at 60:40 and 40:60), and the second factor was the level of CM to replace soybean meal (SBM) in a concentrate ratio at 100:0, 75:25, 50:50, 25:75, and 0:100, respectively. It was found that in vitro DM degradability and the concentration of propionic $\left(\mathrm{C}_{3}\right)$ were significantly increased $(p<0.05)$, while the potential extent of gas production $(a+b)$, acetate $\left(C_{2}\right)$, acetate and propionate $\left(C_{2}: C_{3}\right)$ ratio, and protozoal population were reduced $(p<0.05)$ by lowering the R:C ratio and the replacement of SBM by CM. In addition, rumen $\mathrm{CH}_{4}$ production was mitigated $(p<0.05)$ with increasing levels of CM for SBM. In this study, $\mathrm{CM}$ has the potential to improve rumen fermentation by enhancing $\mathrm{C}_{3}$ concentration and DM degradability, reduced methane production, and $C_{2}: C_{3}$ ratio. The effects were more pronounced $(p<0.05)$ at low levels of roughage.

Keywords: cricket meal; protein; ruminal fermentation; digestibility

\section{Introduction}

The demand for animal products such as meat, milk, and eggs has risen dramatically in recent years as a result of the rapidly expanding human population. A promising alternative to traditional livestock to meet rising demand for meat-like products is insects. Insect protein has advantages over plant and animal protein sources, including rapid 
conversion from organic substrate to insect biomass, low water consumption, and low greenhouse gas emissions [1]. Greenhouse gas emissions from livestock farming are high, mainly caused by methane emanating from rumen fermentation [2]. Various dietary and animal management techniques have been proposed to reduce ruminant methane emissions [3]. Feeding is a significant cost factor in livestock production, and feed costs contribute 60-80 percent of overall production expenses [4]. Hence, it is interesting to search for alternative feed opportunities as a strategy for meeting future feed needs. One strategy from the global community is to investigate new protein sources. In Africa, South America, Asia, and Oceania, insects have been a traditional food source in these regions but have recently also gained interest as alternative protein sources in other parts such as Europe and North America [5]. Feeding insects to both non-ruminants and ruminants has recently been recommended [6]. Several insect species have been evaluated for their potential as feed for domesticated animals, including black soldier fly larva, mealworm, grasshopper, locust, house fly maggot, silkworm, and cricket [5]. Worms are readily available, easily accessible, and widely accepted as a source of high-quality protein (55\%) in the form of food or feed [7]. Marareni and Mnisi [8] reported that mopane worm (Imbrasia belina) showed potential to replace soybean meal in Jumbo quail feed without compromising their performance and health status. Recently, the use of edible insects as high-protein feed sources has increased, and cricket has shown economic production potential [9]. Cricket (Gryllus bimaculatus) contains $54.10 \%$ crude protein (CP), $6.90 \%$ crude fiber (CF), $26.90 \%$ fat, and $78.90 \%$ total digestible nutrient (TDN) (DM basis), as well as a variety of essential amino acids including methionine, lysine, histidine, valine, and leucine [5]. Wang et al. [10] reported that cricket also contained 8.7\% chitin. Chitin or chitosan supplementation enhanced chitosan glucosamine interaction with bacterial cell walls, and the resulting permeability changes reduced the population of bacteria [11]. Frye and Calvert [12] found that silkworm larvae had low chitin content and were easier to digest than other insects commonly used as food sources. Their data revealed chitin content of silkworm larvae similar to crickets. Crickets are also considered an excellent source of other macro minerals such as $\mathrm{Mg}, \mathrm{Fe}, \mathrm{Ca}, \mathrm{K}$, and $\mathrm{Na}$ [13]. Insects have been investigated as a protein source in diets of poultry, swine, and fish $[9,14]$. Increasing the amount of Hermetia illucens meal in fish diet led to an increase in saturated fatty acids (SFAs), particularly lauric acid (12:0), with a decrease in valuable polyunsaturated fatty acids (PUFAs) [15,16]. Cullere et al. [17] revealed that broilers fed Hermetia illucens larva meal had higher levels of saturated fatty acids (SFAs), particularly lauric acid (12:0), and lower levels of valuable polyunsaturated fatty acids (PUFAs) in their meat. Microbial degradation and fermentation on the substrate and buffering of volatile fatty acid (VFA) production were the main sources of gas in in vitro rumen fermentation, according to Getachew et al. [18]. Oil or fat, regardless of source, reduced methane emissions, while increased dietary fat concentration and decreased DM and neutral detergent fiber (NDF) digestibility [19]. Oil inhibits methanogenesis by reducing the population or activity of methanogens, eliminating some protozoa, and decreasing nutrient degradation and fermentation. Field cricket (Teleogryllus mitratus), fed as a partial replacement for soybean meal in the diet of 8-20-day broilers, resulted in no negative effects on growth, weight gain, or feed intake [20], while Permatahati et al. [21] found that replacement of fish meal by cricket meal resulted in increased egg production and egg quality of layer quails. However, limited research is available on the use of insects as ruminant feed. The objective of this experiment was to evaluate the effect of cricket meal (Gryllus bimaculatus) (CM) as a protein replacement for soybean meal (SBM) on in vitro fermentation end-products, gas production, nutrient degradability, and methane mitigation.

\section{Materials and Methods}

This study was approved by the Animal Care and Use Committee of Khon Kaen University, Thailand. The experimental feeds were randomly assigned in a $2 \times 5$ factorial arrangement in a completely randomized design (CRD). Treatments were various levels of 
roughage to concentrate $(R: C)$ ratio and replaced soybean meal (SBM) with cricket meal (CM). R:C in a ratio of 60:40 and 40:60, and the replaced SBM with CM in a concentrate ratio at 100:0, 75:25, 50:50, 25:75, and 0:100, respectively. Each treatment contained three runs and three replications (10 treatments $\times 3$ replications +3 bottles of blank).

This study used an adult cricket meal, obtained from cricket farm in Thailand. The cricket farming and the cricket flour production were from Khon Kaen, Thailand. Rice straw, concentrate, and cricket meal were dried by hot air oven at $60^{\circ} \mathrm{C}$ and then ground to a length of $1 \mathrm{~mm}$ (Cyclotech Mill, Tecator, Hoganas, Sweden). Samples of various R:C ratios and concentrate mixtures were used for chemical analysis and in the in vitro gas production experiment. The samples were chemically analyzed by standard methods for dry matter (DM), ash, crude protein (CP), ether extract (EE) [22], neutral detergent fiber (NDF), and acid detergent fibre (ADF), according to Van Soest et al. [23]. This experiment used rumen fluid as a fermentation source from two rumen-fistulated dairy steers $(75 \%$ Holstein Friesian and 25\% Thai native breed, 3 years old) with an average live weight of $320 \pm 10 \mathrm{~kg}$. Before the morning feeding, about $1000 \mathrm{~mL}$ of rumen liquor was collected and combined from each animal. Dairy steers were fed with rice straw ad libitum and concentrate mixture ( $14 \% \mathrm{CP}, 75 \% \mathrm{TDN})$ at $0.5 \%$ of body weight. The method used for in vitro fermentation technique was that of Menke et al. [24], as modified by Kang et al. [25]. During the incubation, gas production of all treatment samples was recorded at 1, 2, 4, 6, 8, $12,24,48,72$, and $96 \mathrm{~h}$. The cumulative gas produced during fermentation was fitted into the model of Orskov and McDonald [26].

When the inoculum ruminal fluid was obtained at 4,8 , and $12 \mathrm{~h}$ after the inoculation, gas production was recorded at each time point, and $\mathrm{pH}$ was measured immediately using a portable $\mathrm{pH}$ temperature meter. Then, the samples of rumen fluid were prepared into two parts. The first portion of $20 \mathrm{~mL}$ was centrifuged at $16,000 \times \mathrm{g}$ for $15 \mathrm{~min}$ and then the supernatant was taken and stored at $-20^{\circ} \mathrm{C}$. Ammonia nitrogen $\left(\mathrm{NH}_{3}-\mathrm{N}\right)$ and a concentration of volatile fatty acids (VFAs), which was $25 \mathrm{~mL}$ of filtered fluid sample, was mixed with $2.25 \mathrm{~mL}$ of $1 \mathrm{M} \mathrm{H}_{2} \mathrm{SO}_{4}$, and then it was centrifuged at $16,000 \mathrm{~g}$ for $15 \mathrm{~min}$, and the supernatant was used for $\mathrm{NH}_{3}-\mathrm{N}$ analysis using the micro-Kjeldahl method [22]. Volatile fatty acids (VFAs); $\left(\mathrm{C}_{2}, \mathrm{C}_{3}\right.$, and $\left.\mathrm{C}_{4}\right)$ analysis was analyzed by HPLC [27]. The second portion, a total direct counting approach, was used on the protozoal population utilizing a hemocytometer, according to the method of Galyean [28]. After incubation, in vitro DM degradability $(\mathrm{g} / \mathrm{kg})$ was determined at 12 and $24 \mathrm{~h}$ [29]. Estimation of $\left(\mathrm{CH}_{4}\right)$ production of rumen was estimated using the VFA proportions [30].

All the experimental data were statistically analyzed by the general linear model (GLM) according to SAS [31]. Treatment means were statistically performed using Tukey's multiple comparison test [32]. Comparisons between the R:C ratio and CM replacement SBM were tested by Duncan's new multiple range test. Differences among means with $p<0.05$ were accepted as being statistically significant.

\section{Results}

\subsection{Chemical Composition of Experimental Feeds}

Chemical compositions of concentrate, cricket meal, and rice straw are listed in Table 1. Concentrate mixtures and $\mathrm{CP}$ concentrations were similar among the formulas, with $\mathrm{CP}$ ranging from 14.0 to $14.4 \%$ and $\mathrm{CM}$ and rice straw containing 68.5 and $2.2 \% \mathrm{CP}$, respectively. CM contained $94.2 \% \mathrm{DM}, 3.4 \%$ ash, $33.1 \% \mathrm{NDF}, 12.7 \% \mathrm{ADF}$, and $12.5 \% \mathrm{EE}$, while rice straw contained $91.6 \% \mathrm{DM}, 9.3 \%$ ash, $75.5 \% \mathrm{NDF}$, and $47.4 \% \mathrm{ADF}$.

\subsection{Measurement of Parameters Based on In Vitro Gas Production Technique and Rumen Degradability of Nutrients}

Gas production from the immediately soluble fraction (a) was not affected $(p>0.05)$ by the R:C ratio, while SBM replacement with CM had no effect on fraction (b) and fraction (c) (Table 2). The potential extent of gas production $(a+b)$ and cumulative gas production at $96 \mathrm{~h}$ were affected by the R:C ratio. Only 100\% CM replacement had an effect $(p<0.05)$, and 
no interactions were observed. In vitro DM degradability $(\mathrm{g} / \mathrm{kg})$ at both 12 and $24 \mathrm{~h}$ was improved $(p<0.05)$ by increasing the $\mathrm{R}: \mathrm{C}$ ratio and level of CM replacing SBM; however, no interactions were observed $(p>0.05)$.

Table 1. Feed ingredients and chemical composition of concentrate, cricket meal (Gryllus bimaculatus), and roughage sources used in the experiment.

\begin{tabular}{|c|c|c|c|c|c|c|c|c|}
\hline \multirow[t]{2}{*}{ Items } & \multicolumn{5}{|c|}{$\begin{array}{l}\text { Replacement Levels of CM for SBM } \\
\text { (\% Fresh Basis) }\end{array}$} & \multirow[t]{2}{*}{$\mathrm{CM}$} & \multirow[t]{2}{*}{ RS } & \multirow[t]{2}{*}{ SBM } \\
\hline & 0 & 25 & 50 & 75 & 100 & & & \\
\hline \multicolumn{9}{|l|}{ Ingredients (\% as fed) } \\
\hline Cassava chip & 60.0 & 60.0 & 58.0 & 55.0 & 55.0 & & & \\
\hline Soybean meal & 16.0 & 12.0 & 8.0 & 4.0 & 0.0 & & & \\
\hline Cricket meal & 0.0 & 4.0 & 8.0 & 12.0 & 16.0 & & & \\
\hline Coconut meal & 7.0 & 7.0 & 7.0 & 8.0 & 8.0 & & & \\
\hline Rice bran & 7.0 & 7.0 & 8.0 & 7.8 & 7.6 & & & \\
\hline Palm meal & 5.0 & 5.0 & 6.0 & 7.0 & 7.0 & & & \\
\hline Molasses & 1.0 & 1.0 & 1.0 & 2.0 & 2.0 & & & \\
\hline Urea & 1.0 & 1.0 & 1.0 & 1.2 & 1.4 & & & \\
\hline Sulfur & 1.0 & 1.0 & 1.0 & 1.0 & 1.0 & & & \\
\hline Mineral mixed & 1.0 & 1.0 & 1.0 & 1.0 & 1.0 & & & \\
\hline Salt & 1.0 & 1.0 & 1.0 & 1.0 & 1.0 & & & \\
\hline \multicolumn{9}{|l|}{ Chemical composition } \\
\hline Dry matter $(\%)$ & 90.3 & 90.8 & 92.3 & 92.7 & 93.1 & 94.2 & 91.6 & 90.5 \\
\hline & & & o dry 1 & & & & & \\
\hline Organic matter & 93.6 & 94.5 & 94.1 & 93.6 & 94.4 & 96.6 & 90.7 & 94.3 \\
\hline Ash & 6.4 & 5.5 & 5.9 & 6.4 & 5.6 & 3.4 & 9.3 & 5.7 \\
\hline Crude protein & 14.0 & 14.1 & 14.0 & 14.3 & 14.4 & 68.5 & 2.2 & 40.1 \\
\hline Neutral detergent fiber & 20.1 & 20.8 & 24.7 & 24.5 & 24.3 & 33.1 & 75.5 & 12.8 \\
\hline Acid detergent fiber & 10.7 & 10.5 & 12.2 & 13.5 & 13.1 & 12.7 & 47.4 & 9.7 \\
\hline Ether extract & 2.2 & 7.2 & 8.0 & 10.6 & 11.3 & 12.5 & - & 13.2 \\
\hline
\end{tabular}

$\mathrm{CM}$, cricket meal; SBM, soybean meal; RS, rice straw.

Table 2. Effect of cricket meal (Gryllus bimaculatus) (CM) on gas production kinetics and in vitro DM degradability.

\begin{tabular}{|c|c|c|c|c|c|c|c|c|c|}
\hline \multirow[t]{2}{*}{ Treatments } & \multirow[t]{2}{*}{ R:C Ratio } & \multirow[t]{2}{*}{ SBM:CM } & \multicolumn{4}{|c|}{ Gas Production Kinetics } & \multirow{2}{*}{$\begin{array}{c}\text { Cumulative Gas } \\
\text { Production at } 96 \mathrm{~h} \\
\text { (mL/0.5 g DM Substrate) }\end{array}$} & \multicolumn{2}{|c|}{$\begin{array}{c}\text { In Vitro DM } \\
\text { Degradability }(\%)\end{array}$} \\
\hline & & & $\mathbf{a}$ & $\mathbf{b}$ & c & $a+b$ & & $12 \mathrm{~h}$ & $24 \mathrm{~h}$ \\
\hline $\mathrm{T} 1$ & $60: 40$ & $100: 0$ & -0.4 & 70.7 & 0.04 & 70.3 & 65.7 & 52.7 & 59.3 \\
\hline $\mathrm{T} 2$ & & $75: 25$ & -0.8 & 71.5 & 0.03 & 70.7 & 68.8 & 55.9 & 59.7 \\
\hline T3 & & $50: 50$ & 1.3 & 69.2 & 0.04 & 71.5 & 69.7 & 57.0 & 60.2 \\
\hline $\mathrm{T} 4$ & & $25: 75$ & 1.1 & 69.8 & 0.04 & 70.9 & 69.1 & 57.5 & 60.5 \\
\hline T5 & & $0: 100$ & 1.6 & 69.1 & 0.04 & 70.7 & 70.2 & 56.5 & 61.6 \\
\hline T6 & $40: 60$ & 100:0 & -3.1 & 76.4 & 0.03 & 73.3 & 65.3 & 62.8 & 62.8 \\
\hline $\mathrm{T} 7$ & & $75: 25$ & -2.7 & 74.3 & 0.03 & 66.1 & 66.7 & 66.5 & 62.4 \\
\hline T8 & & $50: 50$ & -0.8 & 71.5 & 0.03 & 70.7 & 68.7 & 64.6 & 64.0 \\
\hline T9 & & $25: 75$ & -2.2 & 73.4 & 0.03 & 71.7 & 70.1 & 65.1 & 64.1 \\
\hline $\mathrm{T} 10$ & & $0: 100$ & -1.1 & 70.8 & 0.05 & 69.7 & 72.1 & 69.6 & 65.6 \\
\hline SEM & & & 0.38 & 0.58 & 0.008 & 1.42 & 1.18 & 0.45 & 0.58 \\
\hline \multicolumn{10}{|l|}{ Comparison } \\
\hline $\mathrm{R}: \mathrm{C}$ ratio & & & 0.06 & 0.03 & 0.001 & 0.001 & 0.001 & 0.001 & 0.001 \\
\hline SBM:CM & & & 0.92 & 0.95 & 0.006 & 0.04 & 0.03 & 0.04 & 0.03 \\
\hline $\mathrm{R}: \mathrm{C}$ ratio $\times \mathrm{S}$ & SBM:CM & & 0.84 & 0.85 & 0.12 & 0.14 & 0.78 & 0.36 & 0.28 \\
\hline
\end{tabular}

R:C, ratio of roughage to concentrate at 60:40 and 40:60; SBM:CM, soybean meal replacement by cricket meal in a concentrate ratio at 100:0, 75:25, 50:50, 25:75, and 0:100, respectively; a, gas production from immediately soluble fraction, $b$, gas production from insoluble fraction, $c$, gas production rate constant for insoluble fraction, $a+b$, potential extent of gas; SEM, standard error of the mean. 
Increasing levels of $\mathrm{CM}$ replacing SBM resulted in increased cumulative gas production at $96 \mathrm{~h}$ and in vitro DM degradability. Higher gas production and IVDMD were caused by higher concentrate proportion, resulting in higher NFC and lower NDF contents.

\subsection{Volatile Fatty Acid and Methane Production}

Data on total VFA, VFA proportions, and rumen $\mathrm{CH}_{4}$ production are presented in (Table 3 and Figure 1). All parameters except $C_{4}$ were influenced by the $R: C$ ratio, while increasing levels of CM replacing SBM significantly modulated $(p<0.01) \mathrm{C}_{2}, \mathrm{C}_{3}, \mathrm{C}_{2}: \mathrm{C}_{3}$ ratio and rumen $\mathrm{CH}_{4}$ production. However, interactions of the $\mathrm{R}: \mathrm{C}$ ratio and replacement of SBM by $\mathrm{CM}$ were not found in all parameters $(p>0.05)$. Decreasing the roughage to concentrate ratio increased DM degradability, total VFA, and $\mathrm{C}_{3}$ proportions, while decreasing $\mathrm{C}_{2}$ and $\mathrm{CH}_{4}$.

Table 3. Effect of cricket meal (Gryllus bimaculatus) (CM) on in vitro gas production, proportions of volatile fatty acids, and methane production.

\begin{tabular}{|c|c|c|c|c|c|c|c|c|}
\hline \multirow[t]{2}{*}{ Treatments } & \multirow[t]{2}{*}{ R:C Ratio } & \multirow[t]{2}{*}{ SBM:CM } & \multicolumn{4}{|c|}{ Molar Proportions of VFA (mmol/L) } & \multirow[t]{2}{*}{ Total VFA (mmol/L) } & \multirow[t]{2}{*}{$\mathrm{CH}_{4}(\mathrm{mmol} / \mathrm{L})$} \\
\hline & & & $\mathrm{C}_{2}$ & $\mathrm{C}_{3}$ & $\mathrm{C}_{4}$ & $\mathrm{C}_{2}: \mathrm{C}_{3}$ & & \\
\hline $\mathrm{T} 1$ & $60: 40$ & $100: 0$ & 72.0 & 19.0 & 8.9 & 3.8 & 59.8 & 30.7 \\
\hline $\mathrm{T} 2$ & & $75: 25$ & 71.9 & 19.2 & 8.9 & 3.7 & 52.5 & 30.6 \\
\hline T3 & & $50: 50$ & 71.5 & 20.5 & 7.9 & 3.5 & 56.3 & 29.7 \\
\hline $\mathrm{T} 4$ & & $25: 75$ & 69.1 & 22.1 & 8.8 & 3.1 & 68.9 & 28.5 \\
\hline T5 & & $0: 100$ & 65.2 & 24.6 & 10.2 & 2.6 & 63.6 & 26.6 \\
\hline T6 & $40: 60$ & 100:0 & 66.7 & 22.9 & 10.3 & 2.9 & 70.9 & 27.8 \\
\hline $\mathrm{T} 7$ & & $75: 25$ & 61.9 & 27.2 & 11.9 & 2.2 & 78.5 & 25.7 \\
\hline T8 & & $50: 50$ & 56.9 & 31.4 & 11.7 & 1.8 & 73.9 & 21.6 \\
\hline T9 & & $25: 75$ & 56.2 & 30.9 & 12.8 & 1.8 & 73.1 & 21.9 \\
\hline $\mathrm{T} 10$ & & $0: 100$ & 55.1 & 31.5 & 13.4 & 1.7 & 71.2 & 21.5 \\
\hline SEM & & & 0.04 & 0.06 & 0.26 & 0.05 & 1.05 & 0.14 \\
\hline \multicolumn{9}{|l|}{ Comparison } \\
\hline $\mathrm{R}: \mathrm{C}$ ratio & & & 0.001 & 0.001 & 0.08 & 0.001 & 0.004 & 0.001 \\
\hline SBM:CM & & & 0.001 & 0.009 & 0.81 & 0.004 & 0.54 & 0.004 \\
\hline $\mathrm{R}: \mathrm{C}$ ratio $\times \mathrm{S}$ & M:CM & & 0.26 & 0.65 & 0.14 & 0.81 & 0.66 & 0.07 \\
\hline
\end{tabular}

$R: C$, ratio of roughage to concentrate at 60:40 and 40:60; SBM:CM, soybean meal replacement by cricket meal in a concentrate ratio at 100:0, 75:25, 50:50, 25:75, and 0:100, respectively; VFAs, volatile fatty acids; $\mathrm{CH}_{4}$, methane production calculated according to Moss et al. [24]. $\mathrm{CH}_{4}=0.45\left(\mathrm{C}_{2}\right)-0.275\left(\mathrm{C}_{3}\right)+0.4\left(\mathrm{C}_{4}\right)$; SEM, standard error of the mean.

\subsection{Ruminal $\mathrm{pH}$, Ammonia-Nitrogen $\left(\mathrm{NH}_{3}-\mathrm{N}\right)$ Concentration and Protozoal Population}

The $\mathrm{pH}$ of all treatments varied between 6.4 and 6.7 , being lower for substrates with 40:60 R:C ratio compared to 60:40 (Table 4). The R:C ratio and replacement of SBM with $\mathrm{CM}$ was impacted at all levels, resulting in improved $(p<0.01) \mathrm{NH}_{3}-\mathrm{N}$ concentration and protozoal population. The protozoal population reduced $(p<0.01)$ as a result of the R:C ratio, was significantly reduced $(p<0.05)$ in the 60:40 R:C ratio group, and increased in the 40:60 R:C ratio group, while interaction of the $R: C$ ratio and CM replacing SBM had no effect on all parameters. 


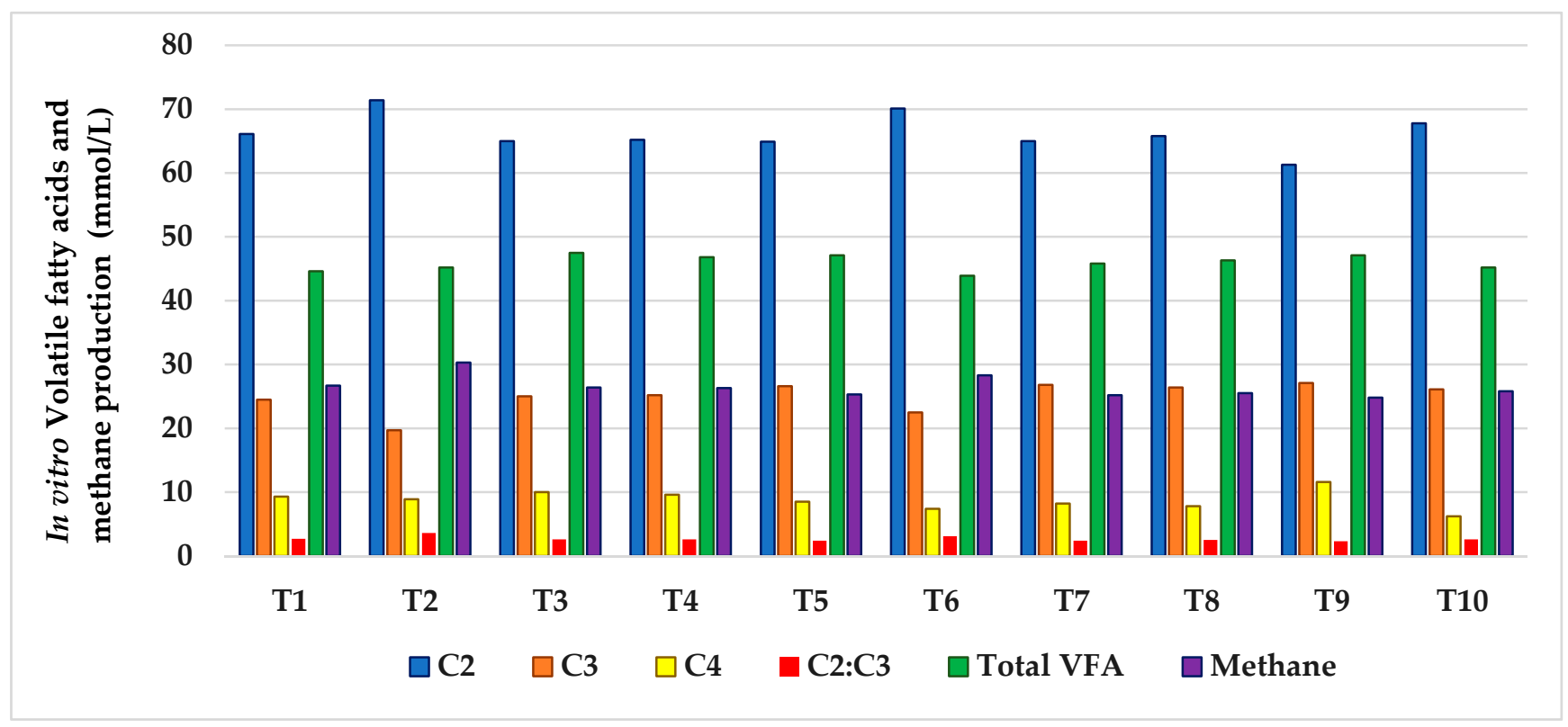

Figure 1. Effect of Cricket meal (Gryllus bimaculatus) (CM) on rumen volatile fatty acids (VFAs) and methane production. T1, 60:40 R:C + 0\%CM; T2, 60:40 R:C + 25\%CM; T3, 60:40 R:C + 50\%CM; T4, 60:40 R:C + 75\%CM; T5, 60:40 R:C + 100\%CM; T6, 40:60 R:C + 0\%CM; T7, 40:60 R:C + 25\%CM; T8, 40:60 R:C + 50\%CM; T9, 40:60 R:C + 75\%CM; T10, 40:60 R:C + 100\%CM.

Table 4. Effect of cricket meal (Gryllus bimaculatus) (CM) in in vitro on rumen $\mathrm{pH}$, ammonia-nitrogen $\left(\mathrm{NH}_{3}-\mathrm{N}\right)$ concentration, and protozoal population.

\begin{tabular}{|c|c|c|c|c|c|}
\hline Treatments & R:C Ratio & SBM:CM & $\mathrm{pH}$ & $\begin{array}{l}\mathrm{NH}_{3}-\mathrm{N} \\
(\mathrm{mg} / \mathrm{dL})\end{array}$ & $\begin{array}{c}\text { Protozoa } \\
\left(\times 10^{5} \text { Cells } / \mathrm{mL}\right)\end{array}$ \\
\hline $\mathrm{T} 1$ & $60: 40$ & 100:0 & 6.5 & 18.7 & 9.1 \\
\hline $\mathrm{T} 2$ & & $75: 25$ & 6.5 & 22.4 & 9.1 \\
\hline T3 & & $50: 50$ & 6.5 & 26.3 & 8.7 \\
\hline $\mathrm{T} 4$ & & $25: 75$ & 6.6 & 25.0 & 7.4 \\
\hline T5 & & 0:100 & 6.7 & 26.0 & 8.1 \\
\hline T6 & $40: 60$ & 100:0 & 6.5 & 23.5 & 6.5 \\
\hline $\mathrm{T} 7$ & & $75: 25$ & 6.4 & 26.6 & 6.1 \\
\hline T8 & & $50: 50$ & 6.4 & 27.8 & 6.4 \\
\hline T9 & & $25: 75$ & 6.4 & 28.1 & 7.2 \\
\hline $\mathrm{T} 10$ & & $0: 100$ & 6.4 & 28.4 & 6.7 \\
\hline SEM & & & 0.14 & 1.28 & 1.42 \\
\hline \multicolumn{6}{|l|}{ Comparison } \\
\hline $\mathrm{R}: \mathrm{C}$ ratio & & & 0.001 & 0.04 & 0.001 \\
\hline SBM:CM & & & 0.72 & 0.03 & 0.02 \\
\hline $\mathrm{R}: \mathrm{C}$ ratio $\times \mathrm{S}$ & $\mathrm{CM}$ & & 0.36 & 0.86 & 0.65 \\
\hline
\end{tabular}

$\mathrm{R}: \mathrm{C}$, ratio of roughage to concentrate at 60:40 and 40:60; SBM:CM, soybean meal replacement by cricket meal in a concentrate ratio at 100:0, 75:25, 50:50, 25:75 and 0:100, respectively; $\mathrm{NH}_{3}-\mathrm{N}$, ammonia-nitrogen concentration $(\mathrm{mg} / 100 \mathrm{~mL})$; SEM, standard error of the mean.

\section{Discussion}

Rice straw was found to be abundantly available in many countries and was fed ad libitum during the experimental period. Wanapat et al. [33] suggested that feeding rice straw with a concentrate mixture containing a high density of energy and protein could be beneficial in increasing its utilization. Insects, as a high protein source, have recently become a popular alternative option. Livestock diets can be supplemented with insects to increase protein concentration. Sánchez-Muros et al. [9] reported that cricket (Gryllus bimaculatus) was an excellent food and feed insect species. The cricket meal used in this experiment contained $68.5 \% \mathrm{CP}, 33.1 \% \mathrm{NDF}, 12.7 \% \mathrm{ADF}$, and $12.5 \% \mathrm{EE}$; this finding was 
similar to that of Jayanegara et al. [5], who stated that cricket meal contained $67.7 \% \mathrm{CP}, 39.3 \%$ NDF, 10.8\% ADF, and 14.5.\% EE. Sánchez-Muros et al. [9] showed that insect ether extract (EE) contained polyunsaturated fatty acids (PUFAs). However, Chakravorty et al. [34] reported that cricket fatty acid profiles consist of $2.34 \%$ linoleic acid, $9.77 \%$ oleic acid, $32.06 \%$ stearic acid, and $50.32 \%$ palmitic acid. Furthermore, insects did not contain only high profiles of crude protein, essential amino acids, minerals, and unsaturated fatty acids (USFA), but also a variety of bioactive compounds such as lauric acid, chitin, peptidase, and flavonoids [35-39]. Inclusion of oil from insects in the diet reduced the production of methane. Lipids can reduce enteric $\mathrm{CH}_{4}$ levels by slowing the fermentation process.

Additionally, Jayanegara et al. [5] discovered that insect meals with a high fiber content had a lower IVDMD and IVOMD than SBM. The high fiber and EE content in insect meals also resulted in low total gas production. Getachew et al. [40] found that adding yellow grease and tallow to total mixed rations supplement results in decreased gas production and in vitro true digestibility. Dietary fat influences the particles of fiber in the rumen by covering the surface of fiber cells, thereby preventing degradation by microbes. Beauchemin et al. [41] noted that unsaturated fatty acids were not more detrimental to fiber digestion, while Jayanegara et al. [42] found that lower digestibility of insect meals results in lower levels of $\mathrm{H}_{2}$ production, which is a key substrate for methanogenesis. Oil or fat from a variety of sources reduced methane emissions. Patra [19] demonstrated that increasing fat content in the diet reduced methane emissions from cattle. Wu et al. [43] revealed that supplementing oleic acid in the diet reduced methane production, while increasing beneficial fatty acids in an in vitro study. In addition, the high EE content leads to reduced methane emissions because some fatty acids, particularly medium chain fatty acids (MCFA), are poisonous to methanogenic archea [44]. The variability in methane emissions is due to the level of insect oils supplementation in feed, suggesting that fatty acids in insect oils play a role in mitigating $\left(\mathrm{CH}_{4}\right)$. In this investigation, rumen $\mathrm{pH}$ varied at 6.4-6.7, which is in agreement with Calabrò et al. [45], who reported that cellulolytic bacteria functioned normally at a $\mathrm{pH}$ of 6.3-7.0 in the rumen, while Russell and Rychlik [46], stated that ruminal $\mathrm{pH}$ is an important parameter that reflects the internal homeostasis of rumen ecology. Kazemi-Bonchenari et al. [47] demonstrated that higher amounts of protein in the diet lead to higher concentrations of ruminal $\mathrm{NH}_{3}-\mathrm{N}$ in the rumen. Proteins in the rumen are broken down into ammonia by proteolytic microbes [48]. Jayanegara et al. [49] showed that the concentration of rumen degradable protein in concentrate was higher than in forage, thereby contributing to higher ammonia production. In the present study, higher levels of concentrate diet and levels of CM used to replace SBM enhanced ruminal $\mathrm{NH}_{3}-\mathrm{N}$ concentration. This is most likely owing to the high protein content of CM. It could also be attributed to the ability of ruminal bacteria to produce stimulatory substances and even protein, or to changes in the abundance of microbes with proteolytic activity. Furthermore, changing the R:C ratio in the diet from 60:40 to 40:60 increased the ruminal $\mathrm{NH}_{3}-\mathrm{N}$ concentration. Similarly, Phesatcha et al. [50] and Viennasay et al. [51] discovered that rumen $\mathrm{NH}_{3}-\mathrm{N}$ concentrations increased dramatically with decreasing $\mathrm{R}: \mathrm{C}$ ratio.

Protozoal populations tended to increase with the use of high-concentrate sources of carbohydrate, which benefited protozoal growth [52]. Boussaada et al. [53] reported that Eucalyptus globulus essential oil extracts decreased the methanogenic population and total number of protozoa in in vitro experiments due to the effect of secondary metabolite compounds in eucalyptus, which had antiprotozoal activities. Reducing the amount of $\mathrm{H}_{2}$ producers such as protozoa in the rumen is an essential strategy in lowering methane production [54]. Our results indicated that supplementation of CM containing oil mitigated protozoal numbers and $\mathrm{CH}_{4}$ production in the rumen. Ciliate protozoa play an important role in rumen methanogenesis due to their relationship with methanogens that attach to cell membrane surfaces [55]. Methanogenesis can be inhibited by the addition of oil that reduces the population or activity of methanogens by the partial elimination of protozoa. In addition, Belanche et al. [56] revealed that chitosan reduced ruminal methane emissions and methanogen populations. 


\section{Conclusions}

Cricket meal is rich in protein and could be used to replace soybean meal as a protein supplement to improve propionate production in the rumen, reduce protozoal population, and mitigate methane production. However, further in vivo trials are required for a more detailed investigation of the use of $\mathrm{CM}$ as a source of protein.

Author Contributions: Conceptualization, B.P. and M.W.; Formal analysis, B.P. and M.W.; Investigation, B.P.; Methodology, B.P., K.P., B.V., M.M. and P.T.; Writing-original draft, B.P.; Writing-review and editing, B.P., M.W. and K.P. All authors have read and agreed to the published version of the manuscript.

Funding: Post-Doctoral training scholarship (PD2563-01), Khon Kaen University.

Institutional Review Board Statement: Animal involved in this study were approved by the Animal Care and Use Committee of Khon Kaen University and carried out by the Institute of Animals for Scientific Purpose Development (IAD), Thailand (record no. U1-06878-2560).

Informed Consent Statement: Not applicable.

Data Availability Statement: Not applicable.

Acknowledgments: The first author is sincerely thankful to Khon Kaen University for supporting the Post Doc. Training program, 2020-2021. Special thanks are extended to Tropical Feed Resources Research and Development Center (TROFREC), KKU Post-Doctoral training scholarship (PD2563-01), Department of Animal Science, Faculty of Agriculture, Khon Kaen University for supporting research activities and facilities. Research facilities and supporting materials were kindly provided in addition by the National Research Council of Thailand (NRCT) through the Basic Research Fund (record no. 2564A10302002).

Conflicts of Interest: The authors declare no conflict of interest.

\section{References}

1. Van Huis, A. Potential of insects as food and feed in assuring food security. Annu. Rev. Entomol. 2013, 58, 563-583. [CrossRef] [PubMed]

2. Nelson, G.C.; Rosegrant, M.W.; Koo, J.; Robertson, R.; Sulser, T.; Zhu, T.; Ringler, C.; Msangi, S.; Palazzo, A.; Batka, M.; et al Climate change: Impact on Agriculture and Costs of Adaptation. Int. Food Policy Res. Inst. 2009. [CrossRef]

3. Knapp, J.R.; Laur, G.L.; Vadas, P.A.; Weiss, W.P.; Tricarico, J.M. Invited review: Enteric methane in dairy cattle production: Quantifying the opportunities and impact of reducing emissions. J. Dairy Sci. 2014, 97, 3231-3261. [CrossRef] [PubMed]

4. $\quad \mathrm{Abu}, \mathrm{O}$;; Olaleru, I.F.; Oke, T.D.; Adepegba, V.A.; Usman, B. Performance of broiler chicken fed diets containing cassava peel and leaf meals as replacements for maize and soya bean meal. Int. J. Sci. Technol. 2015, 4, 169-173.

5. Jayanegara, A.; Yantina, N.; Novandri, B.; Laconi, E.B. Evaluation of some insects as potential feed ingredients for ruminants: Chemical composition, in vitro rumen fermentation and methane emissions. J. Indones. Trop. Anim. Agric. 2017, 42, 247-254. [CrossRef]

6. Makkar, H.P.S.; Tran, G.; Heuzé, V.; Ankers, P. State of the art on use of insects as animal feed. Anim. Feed Sci. Technol. 2014, 197, 1-33. [CrossRef]

7. Moyo, S.; Masika, P.J.; Muchenje, V. The potential of Imbrasia belina worm as a poultry and fish feed. A review. J. Anim. Feed Sci. 2019, 28, 209-219. [CrossRef]

8. Marareni, M.; Mnisi, C.M. Growth performance, serum biochemistry and meat quality traits of Jumbo quails fed with mopane worm (Imbrasia belina) meal-containing diets. Vet. Anim. Sci. 2020, 10, 100141. [CrossRef]

9. Sanchez-Muros, M.J.; Barroso, F.G.; Manzano-Agugliaro, F. Insect meal as renewable source of food for animal feeding: A review. J. Clean. Prod. 2014, 65, 16-27. [CrossRef]

10. Wang, D.; Yao, Y.B.; Li, J.H.; Zhang, C.X. Nutriotional value of the field cricket (Gryllus testaceus Walker). Insect Sci. 2004, 11, 275-283. [CrossRef]

11. Chung, Y.C.; Su, Y.P.; Chen, C.C.; Jia, G.; Wang, H.L.; Wu, J.C.G.; Lin, J.G. Relationship between antibacterial activity of chitosans and surface characteristics of cell wall. Acta Pharmacol. Sin. 2004, 25, 932-936. [PubMed]

12. Frye, F.L.; Calvert, C.C. Preliminary information on the nutritional content of mulberry silk moth (Bombyx mori) larvae. J. Zoo Wildl. Med. 1989, 20, 73-75.

13. Kohler, R.; Kariuki, L.; Lambert, C.; Biesalski, H.K. Protein, amino acid and mineral composition of some edible insects from Thailand. J. Asia Pac. Entomol. 2019, 22, 372-378. [CrossRef]

14. Jozefiak, D.; Jozefiak, A.; Kieronczyk, B.; Rawski, M.; Swiatkiewicz, S.; Dlugosz, J.; Engberg, R.M. Insects-a natural nutrient source for poultry-a review. Ann. Anim. Sci. 2016, 16, 297-313. [CrossRef] 
15. Piccolo, G.; Iaconisi, V.; Marono, S.; Gasco, L.; Loponte, R.; Nizza, S.; Parisi, G. Effect of Tenebrio molitor larvae meal on growth performance, in vivo nutrients digestibility, somatic and marketable indexes of gilthead sea bream (Sparus aurata). Anim. Feed Sci. Technol. 2017, 226, 12-20. [CrossRef]

16. Secci, G.; Moniello, G.; Gasco, L.; Bovera, F.; Parisi, G. Barbary partridge meat quality as affected by Hermetia illucens and Tenebrio molitor larva meals in feeds. Food Res. Int. 2018, 112, 291-298. [CrossRef] [PubMed]

17. Cullere, M.; Tasoniero, G.; Giaccone, V.; Acuti, G.; Marangon, A.; Dalle Zotte, A. Black soldier fly as dietary protein source for broiler quails: Meat proximate composition, fatty acid and amino acid profile, oxidative status and sensory traits. Animal 2018, 12, 640-647. [CrossRef]

18. Getachew, G.; Blümmel, M.; Makkar, H.; Becker, K. In vitro gas measuring techniques for assessment of nutritional quality of feeds: A review. Anim. Feed Sci. Technol. 1998, 72, 261-281. [CrossRef]

19. Patra, A.K. The effect of dietary fats on methane emissions, and its other effects on digestibility, rumen fermentation and lactation performance in cattle: A meta-analysis. Livest. Sci. 2013, 155, 244-254. [CrossRef]

20. Wang, D.; Zhai, S.W.; Zhang, C.X.; Bai, Y.Y.; An, S.H.; Xu, Y.N. Evaluation on nutritional value of field crickets as a poultry feedstuff. Asian-Australas. J. Anim. Sci. 2005, 18, 667-670. [CrossRef]

21. Permatahati, D.; Mutia, R.; Astuti, D.A. Effect of Cricket Meal (Gryllus bimaculatus) on Production and Physical Quality of Japanese Quail Egg. Trop. Anim. Sci. J. 2019, 42, 53-58. [CrossRef]

22. Association of Official Analytical Chemists (AOAC). Official Methods of Analysis, 19th ed.; AOAC International: Gaithersburg, MD, USA, 2012.

23. Van Soest, P.J.; Robertson, J.B.; Lewis, B.A. Methods for dietary fiber, neutral detergent fiber, and nonstarch polysaccharides in relation to animal nutrition. J. Dairy Sci. 1991, 74, 3583-3597. [CrossRef]

24. Menke, K.H.; Raab, L.; Salewski, A.; Steingass, H.; Fritz, D.; Schneider, W. The estimation of the digestibility and metabolizable energy content of ruminant feedstuffs from the gas production when they are incubated with rumen liquor in vitro. J. Agric. Sci. 1979, 93, 217-222. [CrossRef]

25. Kang, S.; Wanapat, M.; Viennasay, B. Supplementation of banana flower powder pellet and plant oil sources on in vitro ruminal fermentation, digestibility, and methane production. Trop. Anim. Sci. J. 2016, 48, 1673-1678. [CrossRef] [PubMed]

26. Orskov, E.R.; McDonal, I. The estimation of protein degradability in the rumen from incubation measurements weighted according to rate of passage. J. Agric. Sci. 1979, 92, 499-503. [CrossRef]

27. Mathew, S.; Sagathewan, S.; Thomas, J.; Mathen, G. An HPLC method for estimation of volatile fatty acids of ruminal fluid. Indian J. Anim. Sci. 1997, 67, 805-811.

28. Galyean, M. Laboratory Procedure in Animal Nutrition Research; Department of Animal and Range Sciences, New Mexico State University: Las Cruces, NM, USA, 1989; Volume 188.

29. Van Soest, P.J.; Robertson, J.B. A Laboratory Manual for Animal Science; Cornell University Press: Ithaca, NY, USA, 1985.

30. Moss, A.R.; Jouany, J.P.; Newbold, J. Methane production by ruminants: Its contribution to global warming. Anim. Res. 2000, 49, 231-253. [CrossRef]

31. SAS (Statistical Analysis System). User's Guide: Statistic, 9, 3th ed.; SAS Inst. Inc.: Cary, NC, USA, 2013.

32. Crichton, N. Information point: Tukey multiple comparison test. J. Clin. Nurs. 1999, 8, 299-304.

33. Wanapat, M.; Sundstøl, F.; Garmo, T.H. A comparison of alkali treatment methods to improve the nutritive value of straw. Anim. Feed Sci. Technol. 1985, 12, 295-309. [CrossRef]

34. Chakravorty, J.; Ghosh, S.; Meyer-Rochow, V.B. Nutritional composition of Chondacris rosea and Brachytrupes orientalis: Two common insects used as food by tribes of Arunachal Pradesh, India. J. Asia-Pac. Entomol. 2014, 17, 48-56. [CrossRef]

35. Hanboonsong, Y.; Jamjanya, T.; Durst, P.B. Six-Legged Livestock: Edible Insect Farming, Collecting and Marketing in Thailand; Food and Agriculture Organization of the United Nations: Bangkok, Thailand, 2013.

36. Shumo, M.; Osuga, I.M.; Khamis, F.M.; Tanga, C.M.; Fiaboe, K.K.M.; Subramanian, S.; Ekesi, S.; Van Huis, A.; Borgemeister C. The nutritive value of black soldier fly larvae reared on common organic waste streams in Kenya. Sci. Rep. 2019, 9, 10110. [CrossRef] [PubMed]

37. Veldkamp, T.; Dong, L.; Paul, A.; Govers, C. Bioactive properties of insect products for monogastric animals-A review. J. Insects Food Feed. 2021, 1-14. [CrossRef]

38. Ahmed, E.; Fukuma, N.; Hanada, M.; Nishida, T. Insects as Novel Ruminant Feed and a Potential Mitigation Strategy for Methane Emissions. Animals 2021, 11, 2648. [CrossRef] [PubMed]

39. Bellezza-Oddon, S.; Biasato, I.; Imarisio, A.; Pipan, M.; Dekleva, D.; Capucchio, M.T.; Meneguz, M.; Stefania, B.; Barbero, R.; Gariglio, M.; et al. Black Soldier Fly and Yellow Mealworm live larvae for broiler chickens: Effects on bird performance and health status. J. Anim. Physiol. Anim. Nutr. 2021, 105, 10-19. [CrossRef] [PubMed]

40. Getachew, G.; DePeters, E.J.; Robinson, P.H.; Taylor, S.J. In vitro rumen fermentation and gas production: Influence of yellow grease, tallow, corn oil and their potassium soaps. Anim. Feed Sci. Technol. 2001, 93, 1-15. [CrossRef]

41. Beauchemin, K.A.; McGinn, S.M.; Petit, H. Methane abatement strategies for cattle: Lipid supplementation of diets. Can. J. Anim. Sci. 2007, 87, 431-440. [CrossRef]

42. Jayanegara, A.; Goel, G.; Makkar, H.P.S.; Becker, K. Divergence between purified hydrolysable and condensed tannin effects on methane emission, rumen fermentation and microbial population in vitro. Anim. Feed Sci. Technol. 2015, 209, 60-68. [CrossRef] 
43. Wu, D.; Xu, L.; Tang, S.; Guan, L.; He, Z.; Guan, Y.; Tan, Z.; Han, X.; Zhou, C.; Kang, J.; et al. Influence of oleic acid on rumen fermentation and fatty acid formation in vitro. PLOS ONE 2016, 11, e0156835. [CrossRef]

44. Machmuller, A. Medium-chain fatty acids and their potential to reduce methanogenesis in domestic ruminants. Agric. Ecosyst. Environ. 2006, 112, 107-114. [CrossRef]

45. Calabrò, S.; Cutrignelli, M.I.; Piccolo, G.; Bovera, F.; Zicarelli, F.; Gazaneo, M.P.; Infascelli, F. In vitro fermentation kinetics of fresh and dried silage. Anim. Feed Sci. Technol. 2005, 123, 129-137. [CrossRef]

46. Russell, J.B.; Rychlik, J.L. Factors that alter rumen microbial ecology. Science 2001, 292, 1119-1122. [CrossRef] [PubMed]

47. Kazemi-Bonchenari, M.; Rezayazdi, K.; Nikkhah, A.; Kohram, H.; Dehghan-Banadaky, M. The effects of different levels of sodium caseinate on rumen fermentation pattern, digestibility and microbial protein synthesis of Holstein dairy cows. Afr. J. Biotechnol. 2010, 9, 1990-1998.

48. Owens, F.N.; Qi, S.; Sapienza, D.A. Applied protein nutrition of ruminants-current status and future directions. Prof. Anim. Sci. 2014, 30, 150-179. [CrossRef]

49. Jayanegara, A.; Dewi, S.P.; Ridla, M. Nutrient content, protein fractionation, and utilization of some beans as potential alternatives to soybean for ruminant feeding. Med. Pet. 2016, 39, 195-202. [CrossRef]

50. Phesatcha, K.; Phesatcha, B.; Wanapat, M.; Cherdthong, A. Roughage to concentrate ratio and saccharomyces cerevisiae inclusion could modulate feed digestion and in vitro ruminal fermentation. Vet. Sci. 2020, 7, 151. [CrossRef]

51. Viennasay, B.; Wanpat, M.; Totkul, P.; Phesatcha, B.; Ampapon, T.; Cherdthong, A. Effect of Flemingia macrophylla silage on in vitro fermentation characteristics and reduced methane production. Anim. Prod. Sci. 2020, 60, 1918-1924. [CrossRef]

52. Brown, M.S.; Ponce, C.H.; Pulikanti, R. Adaptation of beef cattle to high-concentrate diets: Performance and ruminal metabolism. J. Anim. Sci. 2006, 84, 25-33. [CrossRef]

53. Boussaada, A.; Arhab, R.; Calabrò, S.; Grazioli, R.; Ferrara, M.; Musco, N.; Thlidjane, M.; Cutrignelli, M.I. Effect of Eucalyptus globulus leaves extracts on in vitro rumen fermentation, methanogenesis, degradability and protozoa population. Ann. Anim. Sci. 2018, 18, 753-767. [CrossRef]

54. Benchaar, C.; McAllister, T.A.; Chouinard, P.Y. Digestion, ruminal fermentation, ciliate protozoal populations, and milk production from dairy cows fed cinnamaldehyde, quebracho condensed tannin, or Yucca schidigera saponin extracts. J. Dairy Sci. 2008, 91, 4765-4777. [CrossRef]

55. Lee, M.R.F.; Harris, L.J.; Dewhurst, R.J.; Merry, R.J.; Scollan, N.D. The effect of clover silages on long chain fatty acid rumen transformations and digestion in beef steers. J. Anim. Sci. 2003, 76, 491-501. [CrossRef]

56. Belanche, A.; Pinloche, E.; Preskett, D.; Newbold, C.J. Effects and mode of action of chitosan and ivy fruit saponins on the microbiome, fermentation and methanogenesis in the rumen simulation technique. FEMS Microbiol. Ecol. 2016, 92, 1. 